\title{
Comparison of manual toothbrushes with different bristle designs in terms of cleaning efficacy and potential role on gingival recession
}

\author{
Emine Cifcibasi ${ }^{1}$, Cenker Zeki Koyuncuoglu ${ }^{2}$, Ulku Baser $^{1}$, Busra Bozacioglu ${ }^{3}$, \\ Kamber Kasali ${ }^{4}$, Serdar Cintan ${ }^{1}$
}

Correspondence: Dr. Emine Cifcibasi Email: ecifcibasi@hotmail.com

\author{
'Department of Periodontology, Faculty of Dentistry, \\ University of Istanbul, Istanbul, Turkiye, \\ ${ }^{2}$ Department of Periodontology, Faculty of Dentistry, \\ University of Istanbul Aydin, Istanbul, Turkiye, \\ ${ }^{3}$ Private Practice, Armadent Dental Clinic, \\ Istanbul, Turkiye, \\ ${ }^{4}$ Department of Biostatistics, Faculty of Medicine, \\ University of Istanbul, Istanbul, Turkiye
}

\section{ABSTRACT}

Objective: The aim was to compare the efficacy of plaque control and potential effects on gingival recession of the toothbrushes with angled and straight bristles. Materials and Methods: A total of 40 healthy dental students ( 25 females and 15 males; age range: 23-25 years) participated and two study groups were constituted. Participants were randomly distributed into two groups to use either angled or standard design manual tooth brushes with soft bristles. Oral hygiene indicators and soft tissue levels were monitored for 6 months. Plaque index, gingival index (GI), probing depth, clinical attachment level, and bleeding on probing were measured at six sites. Vertical recession (VR) and horizontal recession (HR) were also recorded. All measurements were repeated at 3 and 6 months. Results: Plaque scores were reduced significantly at 6 months compared to baseline in both groups $(P<0.05$ and $P<0.005$ in criss-cross and standard design brushes, respectively). Mean GI scores of the criss-cross design were reduced significantly at 6 months $(P<0.05)$. Inter-group comparisons revealed that gingival recession (GR) values were not statistically significant $(P>0.05)$ at baseline, 3 and 6 months suggesting no pronounced impact of bristle design in terms of GR $(\mathrm{VR}=0.596$, $\mathrm{HR}=0.572 ; \mathrm{VR}=0.884, \mathrm{HR}=0.572 ; \mathrm{VR}=0.884, \mathrm{HR}=0.572$ in the groups). Conclusions: Bristle design has little impact on plaque removal capacity of a toothbrush. Both designs are safe enough to prevent GR as long as soft bristle material is used.

Key words: Bristle design, gingival margin, gingival recession, oral hygiene, plaque removal, randomized controlled trial, tooth brush

\section{INTRODUCTION}

Dental plaque is a requisite etiologic factor in the inception and development of caries and periodontal diseases. ${ }^{[1,2]}$ Loe et al. showed the essential role of dental plaque to the etiology of gingivitis and removal of plaque can reverse this process. ${ }^{[1]}$ Thus, effective plaque control is critical to improve oral health. ${ }^{[3]}$ However, controlling plaque accumulation for preventing gingivitis and/or periodontitis and decays effectively is influenced by a number of individual and material based factors. These main factors can be summarized as the design of the toothbrush, the skill of the individual using the brush, and toothbrushing frequency and duration of use. ${ }^{[4]}$ The last two factors represent individual toothbrushing behavior and are affected by learning experience, motivation and manual capacity and can of course be improved with good co-operation established between dentists and patients. However,

\footnotetext{
How to cite this article: Cifcibasi E, Koyuncuoglu CZ, Baser U, Bozacioglu B, Kasali K, Cintan S. Comparison of manual toothbrushes with different bristle designs in terms of cleaning efficacy and potential role on gingival recession. Eur J Dent 2014;8:395-401. 
the first factor represent technology improvement and is affected by the physical and mechanical properties of the toothbrush bristles and the shape, size and morphometry of the tooth brush heads and handles. ${ }^{[5]}$ Furthermore, it was well-known that most people use a simple horizontal tooth brushing action and brush their teeth for the duration markedly shorter than optimal time. ${ }^{[6]}$ Manufacturers of toothbrushes aim for innovations in the brush head design that will help to compensate for nonideal toothbrushing technique and time. ${ }^{[7]}$ The more basic designs include tooth brushes with standard (straight) bristles and more advanced models with angled (CrissCross ${ }^{\circledR}$ ) bristles specially aiming at helping to remove plaque from teeth and along the gum line. ${ }^{[8,9]}$ The advanced toothbrushes has the potential to remove greater amounts of plaque, especially from the gum lines and approximal surfaces than conventional tooth brushes incorporating straight bristles. ${ }^{[7,9]}$ On the other hand, there has been conflicting results whether which design is more capable of effective plaque control. ${ }^{[4-6,8-11]}$ Gingival recession (GR) is defined as the exposure of the root surface due to the displacement of the gingival margin apical to the cemento-enamel junction (CEJ). First toothbrushes were developed solely to effectively remove plaque and they had hard and then medium bristle softness. Recently, soft bristles were used in straight and criss-cross brushes as hard and medium bristle stiffness could have the potential for causing soft tissue damage.

To the best of our knowledge, there has been no clinical evidence that a toothbrush with criss-cross bristles does not cause soft tissue trauma after long-term usage. Therefore, the purpose of this single-blind, parallel-group clinical study was to compare the efficacy of plaque control and potential effects on gingival recession of the two different toothbrush models.

\section{MATERIALS AND METHODS}

\section{Study population}

A total of 40 healthy dental students ( 25 females and 15 males; age range: 21-25 years) included in this randomized controlled trial based on the following inclusion criteria: (1) Good general and oral health, (2) six evaluable teeth (excluding third molar) in each quadrant with no crowns, orthodontic appliances, (3) no oral lesions or periodontal pockets $\geq 3 \mathrm{~mm}$ or loss of attachment/recession $\geq 2 \mathrm{~mm}$. Subjects were excluded from the study based on the following exclusion criteria: (1) Muco-gingival problems,
(2) smoking habit, (3) pregnancy, (4) having fixed, removable or implant prosthesis, presence of cervical abrasions, caries or restorations, (5) having the medical condition that causes impaired salivary function, and compromised immune function or effects gingiva. All patients were informed about the nature of the study and their signed informed consent was obtained prior to study procedures. This study was approved by the University Ethical Review Board.

\section{Tootbrush design}

Two manual toothbrushes with different bristle arrangements were used: Standard, flat-trim bristles (Oral-B Indicator, 35-soft, P and G, Istanbul, Turkey) and CrissCross ${ }^{\circledR}$ bristles; multisection power tip bristles; outer gingival stimulators (Oral- ${ }^{\circledR}$ Pro-Expert Cross Action Gum Care Manual Toothbrush, P and G, Istanbul, Turkey).

\section{Study procedures}

Study subjects received no dental debridement, but were individually instructed in the modified Bass technique ${ }^{[12,13]}$ and given a study toothbrush randomly by the flipping of a coin at baseline by one of the investigators (SC) who was not involved in the clinical procedures. The participants were instructed to brush their teeth twice daily using given toothbrushes during the study period. They were also asked to refrain from all oral hygiene procedures and chewing gum for $12 \mathrm{~h}$ prior to their appointment before each measurement appointment. The toothbrushes and toothpastes (a basic toothpaste with no antiplaque agent (Ipana Classic Taste, P and G, Istanbul, Turkey) were delivered according to the allocation of randomization and all clinical indices were performed and recorded by another investigator (EC) blinded to randomization. Plaque index (PI) was scored according to the criteria of the Quigley and Hein index ${ }^{[14]}$ modified by Turesky: ${ }^{[15]}$ Score 0: No plaque. Score 1: Separate flecks of plaque at the gingival margin of the crown. Score 2: A thin continuous band of plaque at the gingival margin of the crown. Score 3: A band of plaque wider than $1 \mathrm{~mm}$ but covering less than one-third of the crown of the tooth. Score 4: Plaque covering less than two-thirds of the crown of the tooth. Score 5: Plaque covering more than two-thirds of the crown of the tooth. The dental plaque on the teeth was disclosed with basic fuchsin tablets. Gingival index (GI) ${ }^{[16]}$ was scored according to the following criteria by Silness and Loe: Score 0: Absence of inflammation. Score 1: A slight change in color and little change in texture. Score 2: A moderate redness, edema and hypertrophy and bleeding on probing (BoP). Score 3: A marked 
redness, hypertrophy and tendency to spontaneous bleeding. Probing depth (PD) (distance from the gingival margin (GM) to the bottom of the sulcus) and clinical attachment level (CAL) (distance between CEJ and bottom of the sulcus) were also measured. All measurements were taken at six sites around all teeth excluding the third molars. The presence of $\mathrm{BoP}^{[17]}$ was recorded almost $10 \mathrm{~s}$ after each PD measurement. GR was evaluated and classified according to Miller classification. ${ }^{[18]}$ Vertical recession (VR) (distance between CEJ and the gingival margin), horizontal recession (HR) (mesio-distal distance of denuded tooth surface at enamel-cement level) and gingival margin location (GML) (location of gingival as referenced to CEJ) was measured using a Williams Probe (Hu-Friedy Manufacturing, Chicago, IL, USA) and rounded to the nearest $0.5 \mathrm{~mm}$. Volpe-Manhold index $(\mathrm{VMI})^{[19]}$ was used to detect calculus deposits on the lingual surfaces of the six anterior mandibular teeth. The measurements were repeated at 3 and 6 months by the same single, calibrated examiner (EC) blinded to randomization. During the study period, use of mouthrinses and gels was prohibited.

\section{Statistical analysis}

Statistical analyses were performed with a software program (SPSS version 21.0, IBM, Chicago, USA). The normality of data distribution was assessed using the Kolmogorov-Smirnov test, which indicated that the data were not normally distributed. The collected data within the groups were analyzed using Friedman nonparametric test. After the Bonferroni correction, data were considered as statistically significant when $P<0.016$. The differences between groups were compared with Mann-Whitney U-test. Intraexaminer calibration was analyzed using the Cohen $\kappa$ test. The initial intraexaminer $\kappa$ values were 0.96 (PI) and 0.86 (GR) for the examiner. $P<0.05$ considered as statistically significant difference and all $P$ values were two-tailed.

\section{RESULTS}

\section{Demographic and clinical findings}

The demographic information of study subjects are shown in Table 1 . There were no statistically significant difference in age $(23.35 \pm 0.67 ; 23.05 \pm 0.22$, respectively) between the groups. All subjects were dental students and there were no smokers in both groups. Of the 45 students initially recruited into the study, 40 accomplished successively. Five subjects were lost because they did not adhere the strict "routine daily tooth brushing" rule of the study.
Tooth brushes were replaced with brand new ones after 3 months use.

\section{Evaluation of plaque and gingival indices}

Table 2 presents plaque-related variables during 6 months period. The initial oral hygiene and gingival bleeding parameters did not exhibit significant differences between groups $(P>0.05$; $\mathrm{PI}=0.107 ; \mathrm{GI}=0.322)$. Mean plaque scores were reduced significantly at 6 months compared with baseline in both groups $(P<0.05$ and $P<0.005$ in criss-cross and standard design brushes, respectively) demonstrating good and equivalent plaque removal capacity of the two brushes. Of 20 participants in

\begin{tabular}{|c|c|c|}
\hline Parameters & Criss-cross & Standard \\
\hline Mean age $\pm S D$ & $23.35 \pm 0.67$ & $23.05 \pm 0.22$ \\
\hline Range & $23-25$ & $23-24$ \\
\hline Gender (female/male) & $13 / 7$ & $12 / 8$ \\
\hline Smokers & None & None \\
\hline
\end{tabular}

Table 2: Periodontal parameters associated with plaque removal efficacy of the two tooth brushes during study period

\begin{tabular}{|c|c|c|c|c|}
\hline \multirow[t]{2}{*}{ Parameters } & \multicolumn{3}{|c|}{ Mean $\pm S D$ (median) } & \multirow[t]{2}{*}{$P$} \\
\hline & Baseline & 3 months & 6 months & \\
\hline \multicolumn{5}{|l|}{$\mathrm{PI}$} \\
\hline Criss-cross & $\begin{array}{c}1.54 \pm 0.52 \\
(1.49)\end{array}$ & $\begin{array}{c}1.62 \pm 0.60 \\
(1.49)\end{array}$ & $\begin{array}{c}1.33 \pm 0.49 \\
(1.15)^{*}\end{array}$ & 0.004 \\
\hline Standard & $\begin{array}{c}1.82 \pm 0.63 \\
(2.00)\end{array}$ & $\begin{array}{c}1.61 \pm 0.47 \\
(1.69)\end{array}$ & $\begin{array}{c}1.27 \pm 0.50 \\
(1.12)^{\star *}\end{array}$ & 0.005 \\
\hline \multicolumn{5}{|l|}{ GI } \\
\hline Criss-cross & $\begin{array}{c}0.08 \pm 0.12 \\
(0.05)\end{array}$ & $\begin{array}{c}0.06 \pm 0.09 \\
(0.00)\end{array}$ & $\begin{array}{c}0.05 \pm 0.08 \\
(0.01)^{*}\end{array}$ & 0.003 \\
\hline Standard & $\begin{array}{c}0.04 \pm 0.05 \\
(0.02)\end{array}$ & $\begin{array}{c}0.04 \pm 0.07 \\
(0.00)\end{array}$ & $\begin{array}{c}0.06 \pm 0.12 \\
(0.00)\end{array}$ & 0.850 \\
\hline \multicolumn{5}{|l|}{ PD } \\
\hline Criss-cross & $\begin{array}{c}1.34 \pm 0.33 \\
(1.31)\end{array}$ & $\begin{array}{c}1.27 \pm 0.26 \\
(1.26)\end{array}$ & $\begin{array}{c}1.25 \pm 0.26 \\
(1.26)^{\star *}\end{array}$ & 0.034 \\
\hline Standard & $\begin{array}{c}1.36 \pm 0.19 \\
(1.32)\end{array}$ & $\begin{array}{c}1.37 \pm 0.18 \\
(1.33)\end{array}$ & $\begin{array}{c}1.38 \pm 0.18 \\
(1.34)\end{array}$ & 0.084 \\
\hline \multicolumn{5}{|l|}{ BoP } \\
\hline Criss-cross & $\begin{array}{c}0.15 \pm 0.18 \\
(0.07)\end{array}$ & $\begin{array}{c}0.08 \pm 0.09 \\
(0.04)\end{array}$ & $\begin{array}{c}0.08 \pm 0.07 \\
(0.06)\end{array}$ & 0.267 \\
\hline Standard & $\begin{array}{c}0.05 \pm 0.07 \\
(0.01)\end{array}$ & $\begin{array}{c}0.07 \pm 0.07 \\
(0.06)\end{array}$ & $\begin{array}{c}0.05 \pm 0.05 \\
(0.05)\end{array}$ & 0.316 \\
\hline \multicolumn{5}{|l|}{ CAL } \\
\hline Criss-cross & $\begin{array}{c}1.31 \pm 0.32 \\
(1.30)\end{array}$ & $\begin{array}{c}1.25 \pm 0.27 \\
(1.25)\end{array}$ & $\begin{array}{c}1.22 \pm 0.26 \\
(1.24)^{* *}\end{array}$ & 0.023 \\
\hline Standard & $\begin{array}{c}1.32 \pm 0.19 \\
(1.27)\end{array}$ & $\begin{array}{c}1.32 \pm 0.18 \\
(1.27)\end{array}$ & $\begin{array}{c}1.34 \pm 0.19 \\
(1.28)\end{array}$ & 0.075 \\
\hline
\end{tabular}


each group, mean PI scores were reduced at 6 months compared with baseline in 16 participants using standard design and in 14 subjects using criss-cross design. Four participants using standard design and 6 using criss-cross design had higher mean PI levels. A pattern similar to that of mean PI scores was observed in mean GI scores of the criss-cross design which was also successfull to reduce gingival inflammation at 6 months significantly $(P<0.05)$. Of 20 participants in each group, mean GI scores decreased in 5 participants using standard design and in 11 subjects using criss-cross design, increased in 5 participants using standard design and in 2 participants using criss-cross design. Mean GI scores remained steady in 10 participants using standard design and in 7 participants using criss-cross design. Furthermore, the comparison of mean PI and GI scores between test and control group during the course of this study was not statistically significant at 3 and 6 months, respectively $(P>0.05 ; \mathrm{PI}=0.829, \mathrm{GI}=0.306$; $\mathrm{PI}=0.616, \mathrm{GI}=0.875)$.

Probing depth, bleeding on probing and clinical atachment level

Probing depth improved better in subjects using criss-cross design as a result of resolution of mild inflammation at gingival margin and a slight gain in CAL $(P<0.05)$. However, inter-group comparisons revealed no statistically significant difference regarding $\mathrm{PD}$ and CAL at baseline, 3 months and 6 months, respectively $(P>0.05 ; \mathrm{PD}=0.808$, $\mathrm{CAL}=0.935 ; \mathrm{PD}=0.185, \mathrm{CAL}=0.35 ; \mathrm{PD}=0.110$, CAL $=0.172)$. There was no significant difference between and within groups at any observational period in terms of BoP, whereas participants using criss-cross design had decreased sites positive for $\mathrm{BoP}(P>0.05)$.

\section{Gingival recession}

Data-related to the effects of these two tooth brushes on soft tissue on long-term were shown in Table 3. All GRs detected during the study period was Miller Class I. There was no difference at 3 and 6 months compared with baseline in both groups $(P>0.05)$. Inter-group comparisons revealed that GR values was not statistically significant at baseline, 3 and 6 months $(P>0.05)$ suggesting no pronounced impact of bristle design in terms of $\mathrm{GR}(\mathrm{VR}=0.596, \mathrm{HR}=0.572$; $\mathrm{VR}=0.884, \mathrm{HR}=0.572 ; \mathrm{VR}=0.884, \mathrm{HR}=0.572$ ). There was no incidence of new recession and any change in GML as an evidence to demonstrate bristle texture is more efficient on soft tissue than bristle design if the case is trauma caused by brushing. Furthermore, there were no signs of irritation, sensitivity, tissue trauma or abrasion related to study toothbrushes in clinical evaluations.

\section{Volpe-manhold index}

Table 4 demonstrates calculus index scores as a possible indicator of plaque removal capacity of the toothbrushes used in the present study. Both toothbrushes prevented calculus formation demonstrating adequate plaque removal capacity. Inter-group comparisons revealed that VMI scores were not statistically different between groups at baseline, 3 and 6 months $(P>0.05 \mathrm{VMI}=0.701,0.597$, and 0.661).

\section{DISCUSSION}

This study was designed to evaluate brush-dependent changes in soft tissue location as well as plaque removal efficacy as measured by VR and $\mathrm{HR}$.

\begin{tabular}{|c|c|c|c|c|}
\hline \multirow[t]{2}{*}{ Parameters } & \multicolumn{3}{|c|}{ Mean $\pm S D$ (median) } & \multirow[t]{2}{*}{$P$} \\
\hline & Baseline & 3 months & 6 months & \\
\hline \multicolumn{5}{|l|}{ VR } \\
\hline Criss-cross & $\begin{array}{c}1.15 \pm 2.39 \\
(0.00)\end{array}$ & $\begin{array}{c}1.15 \pm 2.39 \\
(0.00)\end{array}$ & $\begin{array}{c}1.20 \pm 2.59 \\
(0.00)\end{array}$ & 0.368 \\
\hline Standard & $\begin{array}{c}1.48 \pm 2.31 \\
(0.00)\end{array}$ & $\begin{array}{c}1.20 \pm 2.35 \\
(0.00)\end{array}$ & $\begin{array}{c}1.23 \pm 2.39 \\
(0.00)\end{array}$ & 0.779 \\
\hline \multicolumn{5}{|l|}{$\mathrm{HR}$} \\
\hline Criss-cross & $\begin{array}{c}0.20 \pm 0.70 \\
(0.00)\end{array}$ & $\begin{array}{c}0.20 \pm 0.70 \\
(0.00)\end{array}$ & $\begin{array}{c}0.20 \pm 0.70 \\
(0.00)\end{array}$ & - \\
\hline Standard & $\begin{array}{c}0.68 \pm 1.84 \\
(0.00)\end{array}$ & $\begin{array}{c}0.68 \pm 1.84 \\
(0.00)\end{array}$ & $\begin{array}{c}0.68 \pm 1.84 \\
(0.00)\end{array}$ & - \\
\hline \multicolumn{5}{|l|}{ GML } \\
\hline Criss-cross & $\begin{array}{c}0.03 \pm 0.03 \\
(0.02)\end{array}$ & $\begin{array}{c}0.02 \pm 0.03 \\
(0.02)\end{array}$ & $\begin{array}{c}0.02 \pm 0.03 \\
(0.2)^{*}\end{array}$ & 0.034 \\
\hline Standard & $\begin{array}{c}0.04 \pm 0.02 \\
(0.04)\end{array}$ & $\begin{array}{c}0.03 \pm 0.03 \\
(0.04)\end{array}$ & $\begin{array}{c}0.03 \pm 0.03 \\
(0.04)\end{array}$ & 0.125 \\
\hline
\end{tabular}

${ }^{*} P<0.05$. SD: Standard deviation, VR: Vertical recession, HR: Horizontal recession, GML: Gingival margin location, GR: Gingival recession

\begin{tabular}{|c|c|c|c|c|}
\hline \multirow[t]{2}{*}{ Parameter } & \multicolumn{3}{|c|}{ Mean $\pm S D$ (median) } & \multirow[t]{2}{*}{$P$} \\
\hline & Baseline & 3 months & 6 months & \\
\hline \multicolumn{5}{|l|}{ VMI } \\
\hline Criss-cross & $\begin{array}{c}0.44 \pm 0.57 \\
(0.00)\end{array}$ & $\begin{array}{c}0.46 \pm 0.70 \\
(0.00)\end{array}$ & $\begin{array}{c}0.56 \pm 0.70 \\
(0.2)\end{array}$ & 0.017 \\
\hline Standard & $\begin{array}{c}0.58 \pm 0.80 \\
(0.25)\end{array}$ & $\begin{array}{c}0.63 \pm 0.81 \\
(0.25)\end{array}$ & $\begin{array}{c}0.69 \pm 0.81 \\
(0.25)\end{array}$ & 0.019 \\
\hline
\end{tabular}


The results of this study have shown that design of the bristles of a toothbrush had poor influence on oral hygiene condition and GR. Manufacturers have an endeavor to arise plaque control and several processes to check the new toothbrushes for improved oral hygiene performance. The first initial testing used today is laboratory efficacy. ${ }^{[3,7,9,20,21]}$ The second phase to research plaque removal efficiency of new toothbrushes have generally utilized single-use comparative designs using either the subject or a professional to perform the brushing. ${ }^{[8,11,22-26]}$ These studies may ensure a demonstration of gingival health benefits in the long-term. ${ }^{[5,27-29]}$ Sharma et al. have reported that criss-cross bristles angled in opposing directions promote plaque removal from hard-to reach areas, and have advantages over the straight bristle configuration. The researchers concluded that advances in toothbrush design can present greater plaque removal outcomes. ${ }^{[8]}$ In a recent clinical study, the influence of three manual toothbrushes on dental plaque and gingival inflammation was investigated. The PI and GI scores were statistically significantly lower in subjects using the tapered and cross angled soft bristle design toothbrushes than those using the American Dental Association (ADA) standard toothbrushes after 30 days ${ }^{[5]}$ In an another clinical study, criss-cross bristle design used for 1-min (sub-optimal) was compared for plaque removal efficacy with an ADA manual toothbrush used for 2 min (optimal). Both of the toothbrush was achieved efficient plaque removal and didn't differ significantly. ${ }^{[30]}$ Furthermore, criss-cross bristles was found statistically significantly effective in reducing gingivitis. ${ }^{[27,31]}$ However, in a clinical single-blind, cross-over, $24 \mathrm{~h}$ plaque re-growth study on 25 subjects, a computer-based planimetric PI was used to evaluate pre- and post-brushing plaque on lingual surfaces of mandibular posterior teeth. Convex, multilevel or flat trimmed brushhead designs were not able to prove significant superiority over the other brushes. ${ }^{[10]}$ Furthermore, in a comparative plaque removal study, eight branded toothbrushes were used and none of the modifications in brush design actually facilitated plaque removal was concluded. ${ }^{[11]}$ Sripriya and Shaik Hyder Ali evaluated the efficacy of four most commonly used bristle designs of toothbrushes in plaque removal. The results of the clinical study indicated that all the toothbrushes reduced plaque scores significantly compared to the baseline scores, but there is no single superior design of manual toothbrush was found. ${ }^{[32]}$ In a single-blind, cross-over study the performance different toothbrush models for controlling plaque was compared. The three brushes were capable of efficiently removing plaque and the arrangement of the bristles had little effect over the removal of plaque. ${ }^{[3]}$ The findings of our study demonstrated that either bristle designs were almost equally effective in removing dental plaque and preventing gingival inflammation; a slight superiority in favor of criss-cross design for reducing gingival inflammation consistent with the findings of above mentioned studies.

Gingival recession is described as the exposure of the root surface due to the displacement of the gingival margin apical to the CEJ. ${ }^{[34]}$ The etiology of GR is multifactorial; tooth malpositon, orthodontic tooth movement, high muscle attachment and frenal pull, periodontal inflammation and the resultant loss of attachment. Besides these factors, Gorman has confirmed that traumatic toothbrushing might be a contributing factor for GR many years ago. ${ }^{[35]}$ In addition, Page and Sturdivant indicated that localized GRs at early age are considered a growing cause both on esthetical and functional base. ${ }^{[36]}$ and may be related traumatic toothbrushing. ${ }^{[37,38]}$ A significant relationship between bristle hardness and the seriousness of GR was reported. ${ }^{[39]}$ Manual toothbrushes with hard bristles may cause more soft tissue trauma compared to brushes with softer bristles was reported in a recent study ${ }^{[40]}$ However, no significant relation was found between toothbrushing factors (hardness of the bristles, strength of toothbrushing and period of brushing) and GR except the frequency of tooth brushing. ${ }^{[1]}$ In a systematic review concluded that the majority of the cross-sectional studies verified that toothbrushing is related with the development of GR but the knowledge to support or disprove the relation are inadequate. ${ }^{[42]}$ To the best of our knowledge, this is the first study that examined in a longitudinal design the correlation between flat-trim and criss-cross manual soft toothbrushes and GR. There was no advance of GR in subjects using either toothbrush over 6 months. The results of this study have shown that use of toothbrushes with criss-cross bristles are not related with higher occurrence of GR (vertical or horizontal) compared with standard, flat-trim bristles.

In a single-blind, 8-week study confronted the influence of a sonic toothbrush and manual tooth brush in 40 subjects with periodontitis. PD was decreased by approximately $1 \mathrm{~mm}$ over time and there was a significant gain in CAL for both groups. ${ }^{[43]}$ Clinical and microbiological effects of powered toothbrush + triclosan dentifrice were 
compared with manual toothbrush + standard fluoride-dentifrice in periodontal maintenance patients. Both groups demonstrated significant reduction in BoP, PD and in mean total counts of the 40 bacterial species between baseline and 3 years. However, plaque scores and attachment levels almost remained unchanged. ${ }^{[4]}$ Haffajee et al. compared the manual and powered toothbrushes efficacy in periodontal maintenance subjects over a 6-month period of time. Pocket depth, PI and \% of sites exhibiting BoP showed significant reductions from baseline to 6 months in both groups. ${ }^{[45]}$ This study was also designed to monitor potential pocket formation in the long-term in periodontally healthy subjects. Subjects experienced neither pocket formation nor attachment loss as an evidence of good oral hygiene achieved using the two study brushes The findings demonstrated that pocket depth and CAL were slightly altered due to subjects were periodontally healthy. Subjects received no scaling or polishing, however they were individually instructed in the modified Bass technique. Calculus is a mineralized form of dental plaque. Presence of calculus can be an evidence of longstanding plaque present on tooth surfaces. Regular use of both brush design resulted in statistically significant $(P<0.05)$ but clinically negligible new calculus deposition consistent with PI scores.

\section{CONCLUSION}

Within the limits of this study; the design of the bristle of toothbrushes (angled/straight) has minor effect on plaque removal capacity in the long-term usage. In addition, the use of toothbrushes with angled bristles does not cause GR (vertical or horizontal) compared with standard straight bristles.

\section{REFERENCES}

1. Loe H, Theilade E, Jensen SB. Experimental gingivitis in man. J Periodontol 1965;36:177-87.

2. Von der Fehr FR, Löe H, Theilade E. Experimental caries in man. Caries Res 1970:4:131-48.

3. Yankell SL, Shi X, Emling RC, Bucker R, Loudin S. Laboratory evaluation of two bi-level toothbrush products for subgingival access and gingival margin cleaning. J Clin Dent 2000;11:20-3.

4. Frandsen A. Mechanical oral hygiene practices. In: Löe H, Kleinman DV, editors. Dental Plaque Control Measures and Oral Hygiene Practices. Oxford, Washington, DC: IRL Press; 1986. p. 93-116.

5. Ren YF, Cacciato R, Whelehan MT, Ning L, Malmstrom HS. Effects of toothbrushes with tapered and cross angled soft bristle design on dental plaque and gingival inflammation: A randomized and controlled clinical trial. J Dent 2007;35:614-22.

6. Jepsen $\mathrm{S}$. The role of manual toothbrushes in effective plaque control: Advantages and limitations. In: Lang NP, Attstrom R, Löe H, editors. Proceedings of the European Workshop on Mechanical Plaque Control. London: Quintessence; 1998. p. 121-37.
7. Beals D, Ngo T, Feng Y, Cook D, Grau DG, Weber DA. Development and laboratory evaluation of a new toothbrush with a novel brush head design. Am J Dent 2000;13:5A-14.

8. Sharma NC, Qaqish J, Walters PA, Grender J, Biesbrock AR. A clinical evaluation of the plaque removal efficacy of five manual toothbrushes. J Clin Dent 2010;21:8-12.

9. Stiller S, Bosma ML, Shi X, Spirgel CM, Yankell SL. Interproximal access efficacy of three manual toothbrushes with extended, $x$-angled or flat multitufted bristles. Int J Dent Hyg 2010;8:244-8.

10. Staudt CB, Kinzel S, Hassfeld S, Stein W, Staehle HJ, Dörfer CE. Computer-based intraoral image analysis of the clinical plaque removing capacity of 3 manual toothbrushes. J Clin Periodontol 2001;28:746-52

11. Claydon N, Addy M, Scratcher C, Ley F, Newcombe R. Comparative professional plaque removal study using 8 branded toothbrushes. J Clin Periodontol 2002;29:310-6.

12. Bass CC. An effective method of personal oral hygiene; part II. J La State Med Soc 1954;106:100-12.

13. Poyato-Ferrera M, Segura-Egea JJ, Bullón-Fernández P. Comparison of modified Bass technique with normal toothbrushing practices for efficacy in supragingival plaque removal. Int J Dent Hyg 2003;1:110-4

14. Quigley GA, Hein JW. Comparative cleansing efficiency of manual and power brushing. J Am Dent Assoc 1962;65:26-9.

15. Turesky S, Gilmore ND, Glickman I. Reduced plaque formation by the chloromethyl analogue of victamine C. J Periodontol 1970;41:41-3.

16. Loe H, Silness J. Periodontal disease in pregnancy. I Prevalence and severity. Acta Odontol Scand 1963;21:533-51.

17. Ainamo J, Bay I. Problems and proposals for recording gingivitis and plaque. Int Dent J 1975;25:229-35.

18. Miller PD Jr. A classification of marginal tissue recession. Int J Periodontics Restorative Dent 1985;5:8-13.

19. Barnett ML, Charles CH, Gilman RM, Bartels LL. Correlation between Volpe-Manhold calculus index scores and actual calculus area. Clin Prev Dent 1989;11:3-5.

20. Nygaard-Ostby P, Edvardsen S, Spydevold B. Access to interproximal tooth surfaces by different bristle designs and stiffnesses of toothbrushes. Scand J Dent Res 1979;87:424-30.

21. Hotta M, Sekine I, Imade S, Sano A. Evaluation of tapered-end toothbrush bristles regarding effi cacy of access to occlusal fi ssures. J Clin Dent 2002;13:225-7

22. Claydon N, Addy M. Comparative single-use plaque removal by toothbrushes of diff erent designs. J Clin Periodontol 1996;23:1112-6

23. Sharma NC, Qaqish JG, Galustians HJ, King DW, Low MA, Jacobs DM, et al. An advanced toothbrush with improved plaque removal efficacy. Am J Dent 2000;13:15A-9.

24. Cronin MJ, Dembling WZ, Low MA, Jacobs DM, Weber DA A comparative clinical investigation of a novel toothbrush designed to enhance plaque removal efficacy. Am J Dent 2000;13:21A-6.

25. Sharma NC, Qaqish JG, Galustians HJ, Cugini M, Thompson MC Warren PR. Plaque removal efficacy and safety of the next generation of manual toothbrush with angled bristle technology: Results from three comparative clinical studies. Am J Dent 2005;18:3-7.

26. Williams K, Haun J, Dockter K, Ferrante A, Bartizek RD, Biesbrock AR. Plaque removal efficacy of a prototype power toothbrush compared to a positive control manual toothbrush. Am J Dent 2003;16:223-7.

27. Sharma NC, Qaqish JG, Galustians HJ, King DW, Low MA, Jacobs DM, et al. A 3-month comparative investigation of the safety and efficacy of a new toothbrush: Results from two independent clinical studies. Am J Dent 2000;13:27A-32.

28. Cronin MJ, Dembling W, Conforti NJ, Liebman J, Cugini M, Warren PR. A single-use and 3-month clinical investigation of the comparative efficacy of a battery-operated power toothbrush and a manual toothbrush. Am J Dent 2001;14:19B-24.

29. Singh SM, Battista GW, Rustogi KN, DeVizio W, Volpe AR, Petrone ME, et al. The comparative plaque removal efficacy of two advanced manual toothbrush designs in two independent clinical studies. J Clin Dent 2001;12:83-6.

30. Terézhalmy GT, Biesbrock AR, Walters PA, Grender JM, Bartizek RD. Clinical evaluation of brushing time and plaque removal potential of two manual toothbrushes. Int J Dent Hyg 2008;6:321-7.

31. Nathoo S, Chaknis P, Petrone M, DeVizio W, Volpe AR. A clinical comparison of the gingivitis reduction and plaque-removal efficacy of a new manual toothbrush. Compend Contin Educ Dent 2004;25 10 Suppl 2:37-45. 
32. Sripriya N, Shaik Hyder Ali KH. A comparative study of the efficacy of four different bristle designs of tooth brushes in plaque removal. J Indian Soc Pedod Prev Dent 2007;25:76-81.

33. Stroski ML, de Souza Dal Maso AM, Wambier LM, Chibinski AC, Pochapski MT, Santos FA, et al. Clinical evaluation of three toothbrush models tested by schoolchildren. Int J Dent Hyg 2011;9:149-54.

34. Armitage GC. Development of a classification system for periodontal diseases and conditions. Ann Periodontol 1999;4:1-6.

35. Gorman WJ. Prevalence and etiology of gingival recession. J Periodontol 1967;38:316-22.

36. Page RC, Sturdivant EC. Noninflammatory destructive periodontal disease (NDPD). Periodontol 2000 2002;30:24-39.

37. Addy M, Hunter ML. Can tooth brushing damage your health? Effects on oral and dental tissues. Int Dent J 2003;53 Suppl 3:177-86.

38. Litonjua LA, Andreana S, Bush PJ, Cohen RE. Toothbrushing and gingival recession. Int Dent J 2003;53:67-72.

39. Goutoudi P, Koidis PT, Konstantinidis A. Gingival recession: A cross-sectional clinical investigation. Eur J Prosthodont Restor Dent 1997;5:57-61.

40. Zimmer S, Öztürk M, Barthel CR, Bizhang M, Jordan RA. Cleaning efficacy and soft tissue trauma after use of manual toothbrushes with different bristle stiffness. J Periodontol 2011;82:267-71.

41. Tsami-Pandi A, Komboli-Kontovazeniti M. Association between the severity of gingival recessionand possible factors responsible for their presence. Stomatologia 1999,56:125-33.
42. Rajapakse PS, McCracken GI, Gwynnett E, Steen ND, Guentsch A Heasman PA. Does tooth brushing influence the development and progression of non-inflammatory gingival recession? A systematic review. J Clin Periodontol 2007;34:1046-61.

43. O'Beirne G, Johnson RH, Persson GR, Spektor MD. Efficacy of a sonic toothbrush on inflammation and probing depth in adult periodontitis. J Periodontol 1996;67:900-8.

44. Bogren A, Teles RP, Torresyap G, Haffajee AD, Socransky SS, Jönsson $\mathrm{K}$, et al. Long-term effect of the combined use of powered toothbrush and triclosan dentifrice in periodontal maintenance patients. J Clin Periodontol 2008;35:157-64.

45. Haffajee AD, Thompson M, Torresyap G, Guerrero D, Socransky SS. Efficacy of manual and powered toothbrushes (I). Effect on clinical parameters. J Clin Periodontol 2001;28:937-46.

\begin{tabular}{|l|l|}
\hline \multicolumn{2}{|c|}{ Access this article online } \\
\hline Quick Response Code: & Website: \\
& www.eurjdent.com \\
\cline { 2 - 3 } & Source of Support: Nil. \\
\hline
\end{tabular}

